\title{
L'optimisation du réglage de vitesse d'une turbine Kaplan, compte tenu de la forme de la colline et de l'autoréglage
}

\author{
The optimization of frequency regulation \\ by Kaplan units, \\ taking account of the turbine efficiency curves \\ and grid inherent stability
}

PAR G. RANSFORD

INGÉNIEUR A LA SOGREAH, GRENOBLE.

ENGINEER AT THE SOGRLAH, GRENOBLE.

II PARTIE (et fin)

PART II (and End)

\begin{abstract}
Application numérique des principes de calcul cxposés dans la Houlle Blanche, $n^{\prime \prime} 6$, novembre 1959, an cas des groupes bulbe en résean séparé. l'exemple choisi tendrait it indiquer que ces groupes peubent aider à régler la fréquence de. manière utile, à l'opposé de ce qu'on at orl jusqu'ici en raison de leur faible inerlie.
\end{abstract}

\begin{abstract}
A mumerical applicalion of the melhods of analysis described in La Houlle Blanche, $N r .6$, November 1959, to bulb units in an isoluted networl.

The example trealed tends to prove that these units maly usefully contribule to frequency control, whereas formerly this was thonght not to be the case on account of their small inertia.
\end{abstract}

\section{INTRODUCTION}

Ỹous présentons dans ce texte un exemple numérique destiné à concrétiser l'analyse de la première partie parue dans la Honille Blanche, $\mathrm{N}^{\circ} 6$, $1959\left(^{*}\right)$. Il convient cependant de commencer par une explication de l'utilité des trois parametres :

$$
l_{*} \cdot \quad\left(\frac{l_{\max }}{w_{0}}\right), \beta
$$

( ${ }^{\star}$ Erratum : Dans ledil $n^{\prime \prime} 6$, page 770. derniere équation de la page, lire:

$$
\frac{\Delta Q}{Q}=\text {, au lieu de } \frac{\Delta Q}{Q}
$$

The present text is concerned with practical applications of the analysis appearing La Honille Blanche, Nr. 6, $1959\left(^{\star}\right)$. Primarily, we shall be dealing with a numerical example intended to illustrate the seemingly abstruse analysis of Part I, which is actually easily applied in praclice. Some opening remarks deal however with the three last columns of the table published

(*) ERRATum : In the preceding article, the last equation on page 770 should read :

$$
\frac{\Delta Q}{Q}=\text { instead of } \frac{\Delta Q}{\Omega}
$$


figurant dans les dernières colonnes du lableau des résultats de calcul public dans la première partie du texte; en effet, nous n'en avons pas parlé jusqu'ici. Cet exposé ressemble done, à bien des égards, à celui que nous consacrons aux turbines Francis paraissant dans ce même numéro également.

\section{NOTATIONS}

Pour certaines définitions, le lecteur est prie de consulter l'article sur les turbines Francis. D'autres symboles se rapportant aux turbines Kaplan en particulier sont les suivants :

$$
\begin{aligned}
& M=\frac{W_{h}}{\varnothing^{2} \mathrm{H} \sqrt{\mathrm{H}}} \text { ordonnée d'une colline } \\
& \mathrm{N}=\frac{\Omega_{1} \varnothing}{\sqrt{\mathrm{H}}} \text { abscisse d'une colline } \\
& \hat{\delta}=\frac{\mathrm{N}}{2 \mathrm{M}}\left(\frac{\partial \mathrm{M}}{\partial \mathrm{N}}\right)_{\mathrm{Y}} \\
& \varepsilon=\frac{\mathrm{Y}}{\mathrm{M}}\left(\frac{\partial \mathrm{M}}{\partial \mathrm{Y}}\right)_{\mathrm{N}} \\
& \zeta=\frac{\mathrm{N}}{2 \eta_{1}}\left(\frac{\partial \eta}{\partial \mathrm{N}}\right)_{Y} \\
& \varnothing \text { diamètre de la roue }
\end{aligned}
$$

in Part I, these being concerned with the facLors $t_{u} \ldots\left(u_{\max } / w_{0}\right)$ and the form factor $\beta$, about which nothing has yet been said. The treatment is thus similar to that dealing with Francis turbines appearing in the present issue.

\section{NOTATION}

Certain symbols used are defined in the accompanying article on Francis turbines. Others referring specifically to Kaplan units may be recalled :

$$
\begin{aligned}
& \mathrm{M}=\frac{\mathrm{W}_{h}}{\emptyset^{2} \mathrm{H} \sqrt{\mathrm{H}}} \text { ordinate of the turbine } \\
& \text { efficiency diagram }
\end{aligned}
$$

\section{ECART MAXIMUM DE FREQUENCE APRĖS UNE VARIATION BRUTALE DE LA CHARGE MAXIMUM FREQUENCY DISTURBANCE AFTER A SUDDEN LOAD CHANGE}

Le lableau présenté dans la premicre partie fournit, pour les 108 cas étudiés, les valeurs de trois paramètres afférant au comportement d'un groupe dont le réglage obéit au critère de :

$$
\left(\frac{\mathrm{I}}{\left.w_{0}^{2}\right)_{\text {minimum }}}\right.
$$

$1^{\circ} t_{n}$ le temps requis en variables réduites pour atteindre l'écart maximum de fréquence. Ainsi qu'il a été précisé à la page 227 de La Houille Blanche, $\mathrm{n}^{\circ} 3,1958, t_{u}$ vaut approximativement un tiers de la période des oscillations de fréquence qui, éventuellement, suivent la variation de la charge. Cette fraction devrait, à première vue, s'approcher davantage d'un quart de période; il y a cependant un certain retard dans la réponse initiale du groupe qui fait que la phase de démarrage dure relativement plus longtemps. En fait, dans le
The table published in Part I lists values of 3 additional parameters associated with "optimized" governor performance :

(i) $t_{i l}$, the time in dimensionless variables required to attain the extreme frequency variation. Roughly speaking, $t_{n}$ is equivalent to a quarter-period of the frequency oscillations. There is a tendency however for the first frequency variation build-up to occur with a slight lag, so that, as explained on page 212 of La Honille Blanche, $\mathrm{Nr} .3,1958, t_{t}$ in fact approximates more closely to one third of the period of subsequent oscillations, if such occur.

(ii) - $\left(u_{\max } / w_{0}\right)$, the relative value in dimen. sionless notation, of the maximum frequency variation occurring at time $t_{u}$. The minus sign recalls that a throwing-on of load is followed by a speed drop. 
cas des groupes bulbe tout au moins, le comportement est plutôt apériodique, de sorte que le raisomement qui précide, el qui est valable pour les Francis reglées selon notre critere, n'a plus cours.

$2 "--\left(u_{\max } / w_{0}\right)$, la valeur relative, en variables réduites, de l'écart maximum de fréquence, qui se produit au temps $t_{u}$. Le signe « moins $;$ indique, bien entendu, qu'une prise de charge est suivie d'une perte de vitesse.

Rappelons que la variation de la fréquence réelle est liée a u par la formule:

$$
\Delta Q=\frac{c f^{20}}{\tau} \| \Omega_{1}
$$

$3^{\circ} \beta$, un facleur de forme, qui permet d'évaluer $u_{\max }$ connaissant $t_{t}$ et I, l'intégrale dont nous avons longuement parlé ailleurs. En fonction des paramètres de réglage el des caractéristiques de la colline (voir la re partie), la formule pour I est ici la suivante:

$$
\mathrm{I}=\frac{4 \mathrm{~B}+\mathrm{D}}{2 \mathrm{D}(\mathrm{BC}-\mathrm{D})} w_{0}^{2}
$$

B, C, D désignent les coefficients de l'équation de réglage du groupe.

Malheureusement, dans le cas des turbines Kaplan, $t_{n}$ est susceptible de varier bien plus que dans le cas des Francis, où l'approximation $t_{n}=2$ peut etre retenue, faule de mieux, dans certaines applicalions.

Connaissant $l_{\|}$el I, Ja formule domnant $\|_{\text {max }}$ est celle-ci :

$$
u_{\max }=-\beta \sqrt{\mathrm{I} / t_{k}}
$$

\section{EXEMPLE NUMERIQUE}

Nous avons choisi un groupe bulbe, type de turbine qui semble d'autant plus intéressant qu'on ne peut, d'après ce qu'on entend dire parfois, confier à ces groupes le réglage de la fréquence. Cette déficience résulterait de la prépondérance de l'inertie de la colonne d'eau, exprimée par 0, sur celle de la machine (roue et rotor), exprimée par $\tau$. Dans la présente analyse, qui présente la nouveauté d'aborder le problème dans le détail, les caractéristiques choisies sont voisines de celles des turbines projetées pour une usine marémotrice bien connue, sans toutefois s'y identifier.
It is perhaps superfluous to recall that the real frequency variation is related to $u$ by the formula :

$$
\Delta \Omega=\frac{c f^{2} 0}{\tau} u \Omega_{1}
$$

(iii) $\beta$, a form factor. This is useful in determining the value of $u_{\text {mix }}$ from a knowledge of $t_{u}$ and $\mathrm{I}$, the integral so readily evaluated from a knowledge of the governor and efficiency diagram parameters (see Pt. I) :

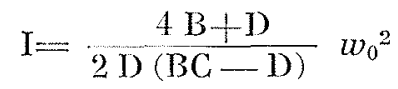

in the present case, where $B, C$ and $D$ denote the coefficients of the differential equation for the speed of the governed turbine.

Unfortunately, in the case of Kaplans, $t_{u}$ is subject to wider variation than in the case of Francis turbines, for which an approximation $t_{u}=2$ can often be used.

Knowing $t_{u}$ and $\mathrm{I}$, the formula for $u_{\max }$ is as follows :

$$
u_{\max }=-\beta \sqrt{\mathrm{I} / t_{u}}
$$

\section{NUMERICAL EXAMPLE}

A bulb unit has been chosen for analysis. This type seems all the more interesting seeing that such turbines, on account of the preponderance of water column inertia, as expressed by $\theta$, compared with machine inertia, $\tau$, cannot, so it is said, be relied on for frequency eontrol. The present study is perhaps the first detailed analysis made of the question. The characteristies chosen resemble, but are not identical with, those contemplated for a well known tidal-power project.

A set of 5.50 metre diameter bulb-type units rotating at 83.3 r.p.m. is designed to work under 


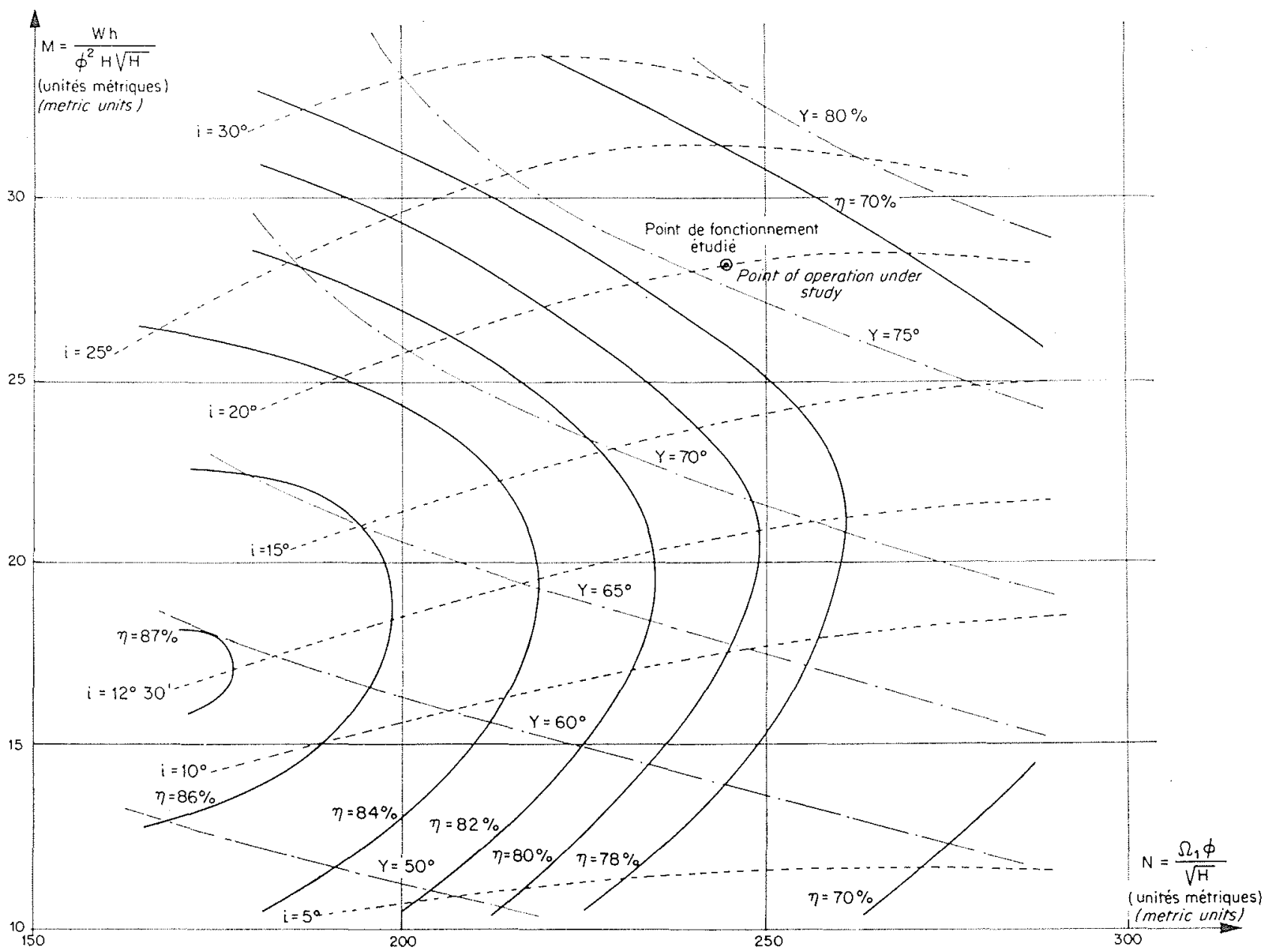

Fili. 1

Un ensemble de turbines bulbe d'un diametre de $5,50 \mathrm{~m}$ et tournant à 83,3 tours par minute fonctionne sous des chutes variables pouvant alier jusqu'à 7 metres environ. On désire cependant étudier le réglagse en réseau séparé à 50 périodes sous une chute de l'ordre de la moitié de ce chiffre, pour une puissance unitaire voisine de $5500 \mathrm{ch}$. Le coefficient d'autoréglage, $\mathrm{A}$, vaut 1,5 . Nous disposons, pour faire cette étude, des documents suivants :

\section{1* La colline générale (fig. 1),}

2" Des collines partielles pour des inclinaisons fixes des pales allant de $0^{\prime \prime}$ à $35^{\circ}$ ", de $5^{\circ}$ en $5^{\circ}$.

'Yout d'abord, nous sommes astreints à utiliser les collines partielles, et le point de fonctionnement à étudier doit par nécessité se retrouver sur l'une d'elles.

Pour $\mathrm{H}=3,50 \mathrm{~m}$, on trouve $\mathrm{N}=245$. La courbe $i=20^{\circ}$ coupe la verticale $\mathrm{N}=245$ à l'ordonnée $M=28,2$, ce qui correspond à $n=0,755$ el heads ranging up to 7 metres. It is however desired to study the frequency control on a separate 50 cycle network at about hall this head, for a power output of belween 5,000 and 6,000 metric horse-power. The inherent stability factor of the network, $A$, equals 1.5. The documents available include :

(a) The general efficiency diagram (fig. 1),

(b) partial efficiency diagrams for fixed blade angle slopes of $0^{\circ}$ to $35^{\circ}$ by $5^{\circ}$ increments.

In the first place, we have to use available partial efficiency diagrams, and the point chosen for study must coincide with one of them.

Now for $\mathrm{H}=3.5$ metres, it is found that $\mathrm{N}=245$ (metric units). The curve for $i=20^{\circ}$ intersects the ordinate $\mathrm{N}=245$ at $\mathrm{M}=28.2$, siving $\eta=0.755$ and $W_{l}=5590$ metric horse-power. 'This point is therefore suitable for study. 
$W_{h}=5590 \mathrm{ch}$. Ce point convient done aux fins de notre étude.

Sur la colline partielle dablie pour $i=20^{\circ}$ (fig. 2), nous trouvons que :

1" $(\partial \mathrm{M} / \partial \mathrm{N})_{\mathrm{Y}}$, la pente de la courbe $\mathrm{Y}=75$ ", qui passe très près de notre point, égale 0,033 , d'oì :

$$
\delta=\frac{\mathrm{N}}{2 \mathrm{M}}\left(\frac{\partial \mathrm{M}}{\partial \mathrm{N}}\right)_{\mathrm{Y}}=0,145
$$

$2^{\prime \prime}(\partial \mathrm{M} / \partial \mathrm{Y})_{\mathrm{N}}$, c'est-à-dire sur une verticale dans la partie inférieure de cette colline, se chiffre à 0,27 , si l'on exprime $Y$ en degrés; donc :

$$
\varepsilon=\frac{\mathrm{Y}}{\mathrm{M}}\left(\frac{\partial \mathrm{M}}{\partial \mathrm{Y}}\right)_{\mathrm{X}}=-0,75
$$

On se souviendra que e traduit la proportionnalité entre l'ouverture du vannage ef le débit (en toute rigueur, il faudrait graduer la colline non pas en fonction de l'ouverture ansulaire des pales, mais en fonction de la course du servomoteur; nous laisserons de côté cette question
On the partial efficiency diagram for $i=20 "$ (fig. 2), we find that :

(a) $(\partial \mathrm{M} / \partial \mathrm{N})_{\mathrm{Y}}$, the slope of the curve $\mathrm{Y}=75^{\prime}$ (which is very near to the point considered) equals 0.033 and hence:

$$
j=\frac{N}{2 M}\left(\frac{\partial M}{\partial N}\right)_{r}=0.145
$$

(b) $(\partial \mathrm{M} / \partial \mathrm{Y})_{\mathrm{N}}$, i.e. on a vertical in the lower half of the diagram, equals 0.27 , Y being expressed in degrees; hence :

$$
s==\frac{Y}{M}\left(\frac{\partial M}{\partial Y}\right)_{N}=0.75
$$

It will be recalled that $\varepsilon$ expresses the degree of linearity between gate opening and discharge. Here the departure from a strictly linear relationship with $\varepsilon=1$ is appreciable.

(c) $(\partial r / \partial N)_{1}$, i.e. on a vertical in the upper

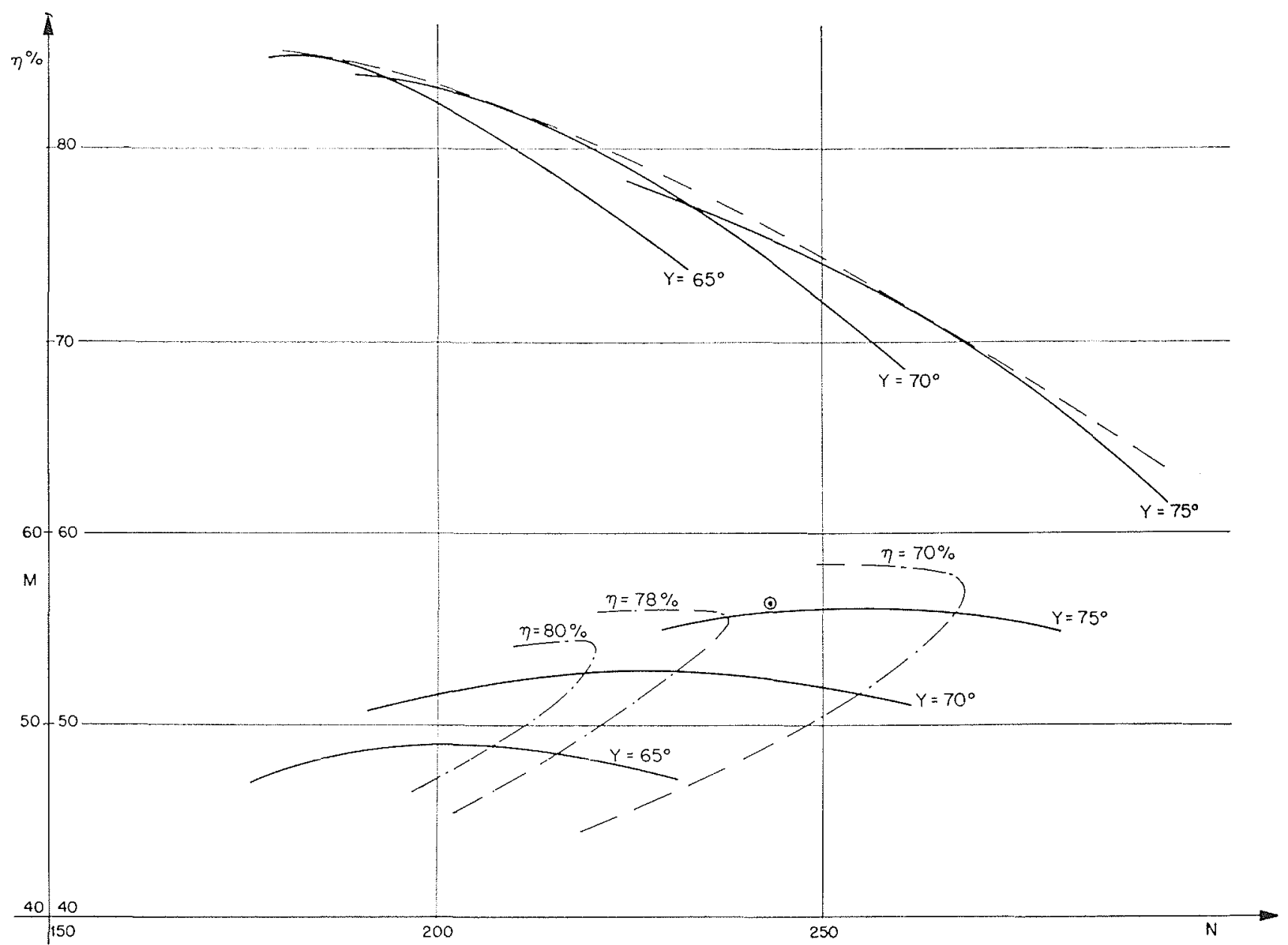

Fig. 2 
ici, faute de renseignements précis sur la manière de réaliser l'embiellagie vannage/servomoteur...). Dans le cas présent, l'écart constaté par rapport à une loi linciare avec $\varepsilon==1$, est notable.

$3 "\left(\partial r_{1} / \partial N\right)_{x}$, c'est-á-dire sur une verticale dans la partie supérieure de cotte colline, égale à -- 0,0021. Par conséquent :

$\zeta=\frac{N}{2 r_{i}}\left(\frac{\partial \eta^{\prime}}{\partial N}\right)=\frac{245}{2 X 0,755}(-0,0021)=--0,34$

Le point de fonctionnement « nominal doit, en ce qui nous concerne ici, correspondre à la course maximum du servomoteur. Si, par exemple, l'ouverture maximum s'identifie à :

$$
\mathrm{Y}=80^{\circ}
$$

un point tel que $\mathrm{M}=32, \mathrm{~N}=-255$ pourrait ètre choisi. Cependant, un tel point de fonctionnement pourrait ne pas correspondre aux desiderata du constructeur en la matière, d'une part, et, d'autre part, il n'y a en définitive aucune raison pour ne pas se baser sur le point à étudicr, pourvu qu'on fasse certaines corrections.

La première de celles-ci est d'évaluer le temps de lancer du groupe en fonction de la puissance fournie à ce point de fonctionnement, et non pas sur la puissance maximum ou nominale.

Done, si l'on suppose que le PD² (rotor et roue) vaut 700 tonnes-mètre carré, le temps de lancer du groupe se chiffre à :

$$
\tau=\frac{(83,3)^{2} \times 700}{270 \backslash 5590}=3,22 \text { secondes }
$$

Par ailleurs, en tenant compte de la dissyncitrie de l'écoulement dans l'aspirateur, on peut supposer que :

$$
\sum \frac{\mathrm{L}}{\mathrm{S}}=1,5 \mathrm{~m} \quad 1
$$

Or, au point à étudier :

$$
\eta=0, \pi 55 ; Q=\frac{5590 \times 75}{1000 \times 3,5 \times 0,755}=159 \mathrm{~m}^{3} / \mathrm{s}
$$

Donc, à ce point, nous trouvons :

$$
0=\frac{1,5 \times 159}{9,8 \times 3,5}=6,95 \mathrm{~s}
$$

sachant que, dans nos hypothèses :

$$
c=f=1
$$

Les paramètres à considérer, à savoir :

$$
\delta=0,145 ; \zeta=-0,34 ; A=1,5 ; \quad \frac{c f^{2} 0}{\tau}=2,16
$$

half of the diagram, equals-0.0021. Consequently:

$\zeta=\frac{\mathrm{N}}{2 r_{1}}\left(\frac{\partial r_{1}}{\partial \mathrm{N}}\right)=\frac{245}{2 \times 0.755}(-0.0021)=-0.34$

The nominal operating point stould be delined for present purposes as one corresponding to the maximum servomotor course. If the maximum opening is, say,

$$
\mathrm{Y}=80^{\circ}
$$

a point such as $M=32, N=255$ could be chosen. However, such a point may not coincide, on the one hand, with what the manufacturer would normally specify, and, on the other, there is no reason for not working in terms of the point under study, provided that certain corrections are made.

The first of these is to calculate the inertia parameter on the basis of the actual power outpul at this point and not on the maximum or nominal outputs).

Thus, if we suppose that the machine inertia (PD2) is 700 t.m2 (note that this is four times the British definition, which would work out at

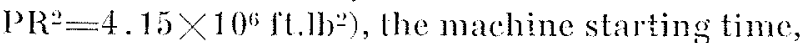
or inertia parameter, works out at :

$$
=\frac{(83.3)^{2} \times 700}{270 \times 5590}=3.22 \mathrm{secs}
$$

Also, after allowing for skewness of flow in the draft tube, it may be assumed that :

$$
\sum \frac{\mathrm{L}}{\mathrm{S}}=1.5 \mathrm{n}^{-1}
$$

Now, at the operating point considered :

$$
\eta=0.755 ; Q=\frac{5590 \times 75}{1000 \times 3.5 \times 0.755}=159 \mathrm{~m}^{3} / \mathrm{s}
$$

Hence, at this point,

$$
0=\frac{1.5 \times 159}{9.8 \times 3.5}=6.95 \mathrm{secs}
$$

with the present assumptions :

$$
c=f=1
$$

The parameters to be considered, viz.,

$$
\delta=0.145 ; \zeta=-0.34 ; A=1.5 ; \quad \frac{c f^{2} \theta}{\tau}=2.16
$$


nous obligent à extrapoler les chirres présentés dans le tableau de la premicre partie du texte.

Les valeurs exactes, retrouvées sur la machine à calculer, sont les suivantes :

$$
\begin{gathered}
\text { (u, 入) pour }\left(\frac{\mathrm{I}}{w_{0}^{2}{ }^{2}}\right)_{\text {min }}=(1,89 ; 2,74) \\
\left(\frac{\mathrm{I}}{\left.w_{0}^{2}\right)_{\min }}=0,0988\right. \\
\left(\lambda_{\max }, \lambda_{\min }\right)=(2,89 ;-2,61) \\
t_{u}=0,237 \\
-\left(\frac{u_{\max }}{w_{0}}\right)=0,396 \\
\beta=0,613
\end{gathered}
$$

Donc, pour une variation brutale de $5 \%$ de la charge, nous devrions nous attendre à une variation maximum de vitesse, et done de fréquence, atteignant :

$$
\begin{aligned}
\left|\left(\frac{\Delta \Omega}{\Omega}\right)_{\max }\right| & =0,396 \frac{c f^{2} \theta}{\tau} w_{0} \\
& =0,396 \times 2,16 \times 0,05 \\
& =4 \%, \text { approximativement. }
\end{aligned}
$$

Cet écart maximum se produira au temps :

$$
\mathrm{T}=6,95 \times 0.237=1,65 \text { seconde }
$$

après la variation de la charge.

La figure 3 illustre l'allure de la variation de vitesse après une prise de charge pour la combi- are such as to require some extrapolation of the figures given in Part I. The correct values, oblained by calculation on the digital computer, are as follows :

$$
\begin{gathered}
(\mu, \lambda) \text { for }\left(\frac{\mathrm{I}}{w_{0}^{2}}\right)_{\min }=(1.89 ; 2,74) \\
\left(\frac{\mathrm{I}}{w_{0}^{2}}\right)_{\min }=0.0988 \\
\left(\lambda_{\max }, \lambda_{\min }\right)=(2.89 ;-2.61) \\
t_{u}=0.237 \\
-\left(\frac{u_{\max }}{w_{0}}\right)=0,396 \\
\beta=0.613
\end{gathered}
$$

Thus, for a load variation of $5 \%$, we could expect a maximum speed variation of :

$$
\begin{aligned}
\left|\left(\frac{\Delta \Omega}{\Omega}\right)_{\max }\right| & =0.396 \frac{c f^{2} \theta}{\tau} w_{0} \\
= & 0.396 \times 2,16 \times 0,05 \\
= & 4 \% \text { approximately }
\end{aligned}
$$

This occurs at a time $\mathrm{T}=6.95 \times 0,237=1.65$ secs. after the load change.

The detailed speed variation is shown in fig. 3 in dimensionless variables for the "optimum"

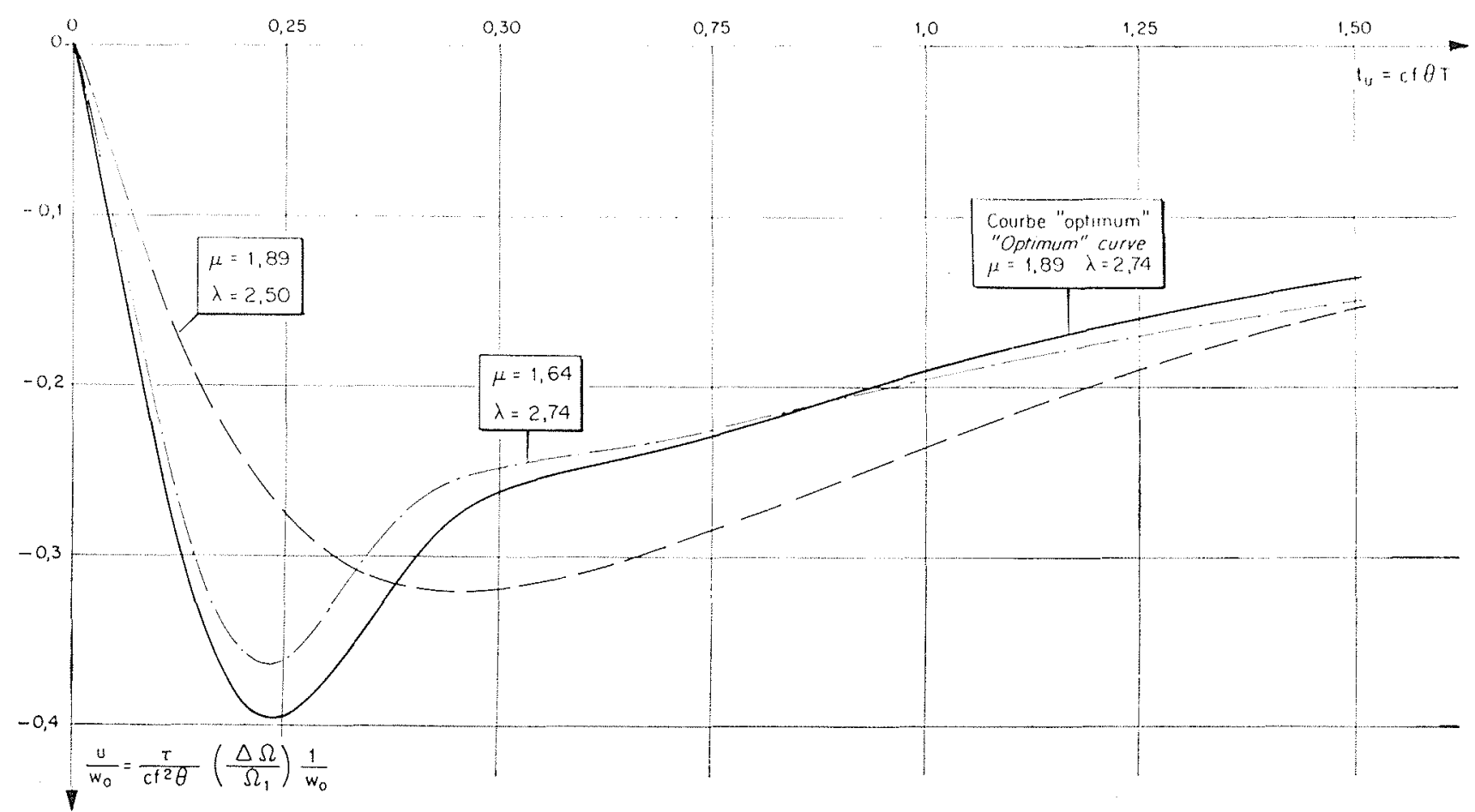

FIG. 3 
naison « optimum » des paramètres de réglage, aussi bien que pour deux combinaisons voisines. On remarquera que la combinaison «optimum», dans le sens précis que nous attribuons à ce terme, s'approche de la frontière de stabilité et conduit à un écart maximum de fréquence un peu plus grand (mais aussi à un amortissement un peu plus accentué), que les points voisins caractérisés par de plus petites valeurs de $\lambda$ ou de $\mu$.

Dans la pratique, il serait souhaitable de choisir des valeurs un peu plus faibles que l' « optimum », pour ces paramètres, ainsi que nous l'avons noté à propos des turbines Francis. Cependant, par souci de simplifier l'exposé, nous maintiendrons nos valeurs primitives dans la suite.

En ce qui concerne le dosage du régleur, nous savons, de manière générale, que :

$$
\begin{aligned}
& \mathbf{K}_{\mu}=\frac{\tau}{c f^{2}\left(j^{2}\right.} \frac{\mathrm{j}}{\varepsilon} \\
& \mathbf{K}_{\lambda}=\frac{\tau}{f^{0}} \frac{\lambda}{\varepsilon}
\end{aligned}
$$

Ces paramètres représentent les dosages tachymétrique et accélérométrique, respectivement.

Dans l'application de ces formules à notre cas, avec $c=f=1$, il est nécessaire d'introduire une correction pour tenir compte de l'ouverture relalive du vannage (environ 0,95 ), l'ouverture à notre point élant de l'ordre de $75^{\circ} 1 / 2$ à $76^{\circ}$, alors que l'ouverture maximum est (disons) de $80^{\circ}$. Il convient de multiplier les $K$, tels que les formules précédentes nous les donnent, par ce facteur de 0,95 , ainsi qu'il ressort d'un examen de l'équation (3) à la page 223 de La Honille Blanche, n" 3 , 1958.

Donc :

$$
\begin{gathered}
\left.\mathrm{K}_{\mu}=0,95 \mid \frac{3,22 \times 1,89}{(6,95)^{2} \times 0,75}\right\rceil=0,16 \mathrm{~s}^{-1} \\
\mathrm{~K}_{\lambda}=0,95\left\{\frac{3,22 \times 2,74}{6,95 \times 0,75}\right\rceil=1,61
\end{gathered}
$$

Dans un régleur à statisme temporaire, nous aboutissons à une pente de came de:

$$
\frac{1}{\mathrm{~K}_{\lambda}}=0,62
$$

le temps de relaxation du dash-pot étant de :

$$
\frac{K_{\lambda}}{K_{\mu}}=-=10 \text { secondes }
$$

Le régleur doit, par conséquent, être très « raide ». Bien entendu, dans la pratique, il serait préférable de choisir une pente de came un peu plus forte, le temps de relaxation restant inchangé; comme nous l'avons déjà expliqué, les combination of governing paramelers just defined, as well as for two other similar ones. It should be noted that the "optimum" combination :

(a) is close to the frontier of stability; and (b) gives a slightly greater maximum speed variation (but a somewhat improved damping) as compared with the other neighbouring, smaller values of $\mu$ or $\lambda$.

In practice, it would therefore be advisable to choose smaller values of these parameters, as already mentioned in dealings with Francis units. However, for the sake of simplicity, the ensuing treatment retains the ones first found.

Turning now to the governor design, we know, generally speaking, that :

$$
\begin{aligned}
& \mathbf{K}_{\mu}=\frac{\tau}{c f^{2} \theta^{2}} \frac{\mu}{\varepsilon} \\
& \mathrm{K}_{\lambda}=\frac{\tau}{10} \frac{\lambda}{\mathrm{c}}
\end{aligned}
$$

These factors represent the tachymetric and accelerometric effects, respectively.

In applying these formulae here, with $c=f=1$, it is necessary to correct for the fact that the wicket gates are open at some $75^{\circ} 1 / 2$ to $76^{\circ}$ only, whereas the full opening (say) is equal to $80^{\circ}$. The relative opening is thus approximately 0.95 , and the values of $K$ found as above must be multiplied by this factor, as a little thought given to eqn. (3) on page 208 of La Houille Blanche, Nr. 3, 1958, shows.

Hence,

$$
\begin{gathered}
\left.K_{\mu}=0.95 \mid \frac{3.22 \times 1.89}{(6.95)^{2} \times 0.75}\right\}=0.16 \mathrm{sec}^{-1} \\
K_{\lambda}=0.95\left\{\frac{3.22 \times 2.74}{6.95 \times 0.75}\right\}=1.61
\end{gathered}
$$

In a dashpot-type governor, these figures correspond to a slope of cam equal to

$$
\frac{1}{\mathrm{~K}_{\lambda}}=0.62
$$

and to a dashpot relaxation time of

$$
\frac{\mathbf{K}_{\lambda}}{\mathbf{K}_{u}}==10 \text { seconds }
$$

The governor should thus be extremely "stifl" for best performance. Of course, in practice, it would be better, as already mentioned, to adopt a slightly greater slope of cam, with the same 
valeurs un peu plis faibles qui en résulteraient pour $\lambda$ et $\mu$. conviendraient mieux.

Ce calcul devarail être repris pour d'autres points de fonctionnement, et la plage des caractéristiques optima du régleur déterminée pour loute la zone d'emploi.

A premiere vue, il semble que les groupes bulbes, décriés parfois à ce point de vue, puissent contribuer utilement au réglage de la fréquence. Il n'est pas sans intérêt de souligner cette conclusion par la citation d'une formule que nous avons vie dans une étude à leur sujet, où il a dé affrmé, pour des vitesses spécifiques dépassant 1000 (ici, $\left.n_{s} \cong 1300\right)$, que :

$$
u_{\text {max }}=-1,75 w_{0}
$$

Dans les notations usuelles, on écrirait:

$$
\left(\frac{\Delta Q}{\Omega_{1}}\right)_{\text {ni: }} \mid=1,75 \frac{c f^{2} 0}{\tau} w_{0}
$$

Point n'est besoin de dire que, appliquée à l'exemple étudié par nous ici, cette formule conduirait à une surestimation grossiere, de l'ordre de quatre à cing fois la vraie valeur. Une étude plus approfondie montrerait si, comme nous le croyons, cette conclusion optimiste s'étend à la gamme habiluelle des conditions d'emploi de ces machines.

Pour terminer, il est intéressant de noter que le comportement de groupes bulbe réglés au mieux, comportement qui est caractérisé par un relour presque apériodique à la vitesse de consigne après une perturbation brutale, est éloigné du comportement familier des Francis (voir l'arlicle publié dans ee numéro). Le parametre qui en rend le mieux comple est sans doute notre facteur de forme, $\beta$, lequel, près de l'unité dans le cals des Francis, diminuerait progressivement lorsqu'on passe des Kaplan classiques aux bulbes. C'est encore un aspect intéressant de l'étude de ce facteur. dashpot stiffness; this would lead to somewhat lower values of $\lambda$ and $\mu$.

These computations should be repeated for other operating points and the governor characteristics varied accordingly. It does seem that, in opposition to what is frequently said, bulb units can usefully participate in frequency regulation. It is perhaps right in conclusion to stress this point by reference to a result we have seen relating to these units, where it was stated that for metric specific speeds in excess of 1.000 (here, $n_{i s} \equiv 1300$ ), the following formula for $u_{m a x}$ is valid:

$$
u_{\text {thax }}=--1.75 w_{0}
$$

or, in more usual notation,

$$
\left|\left(\frac{\Delta \Omega}{\Omega_{1}}\right)_{\max }\right|=1.75 \frac{c f^{20}}{\tau} w_{0}
$$

It is evident that this is often far from the truth : for the case in point, the error is more than a fourfold one! A more complete study would be required to determine whether this optimistic conclusion holds true over the usual range of utilization of such machines, but it is reasonable to suppose that it does.

In conclusion, there is hardly any need to point out that the behaviour of optimally governed bulb units, leaturing an almost aperiodic relurn to the assigned rumning speed after a sudden load change, is far removed from the familiar behaviour of Francis turbines, as described in the accompanying article. The parameter best describing these different hehaviours is no doubt our form factor, $\beta$, which, close to 1 for Francis units, progressively lessens as bulb units are reached. Once again, the utility of this parameter seems to be amply proved.

\section{ERRATUM}

Page 79 du présent numéro, $2^{\circ}$ col., lignes $6,7,8$ et 9 , lire :

« Cet ouvrage est la version allemande de la deuxième édition de l'ouvrage connu de A. J. Stepanoff, traduit par le Dr. Ing. Alexander Haltmeier : Centrifugal and Axial Flow Pumps, publiée chez John Wiley \& Sons, Inc., New York, en 1957. 》 